\title{
MRI Evaluation of Hepatic Iron Overload in $\beta$-Thalassemic Children
}

\author{
ALI E.A. AGALN, M.Sc.*; MOHAMED A. MOHAMED, M.D.*; EBRAHIM M. BADRAIA, M.D.** and \\ ABD EL-MONEM N. DARWISH, M.D.* \\ The Departments of Diagnostic Radiology* and Pediatrics**, Faculty of Medicine, Tanta University
}

\begin{abstract}
Background: $\beta$-Thalassaemia major is a hereditary hemolytic anemia that have amajor complication iron overload. Assessment of Liver Iron Concentration (LIC) is necessary for detection and quantitative staging of iron overload and monitoring of iron-reducing treatments. MRI represents the most available noninvasive technique to assess LIC.
\end{abstract}

The aim of this study was to assess LIC by MRI in multitransfused $\beta$-Thalassemic children.

Patients and Methods: Forty multi-transfused $\beta$ thalassemic children were subjected to clinical evaluation, appropriate laboratory assessment and assessment of LIC by MRI.

T2* weighted gradient echosequence MRI was performed with $1.5 \mathrm{~T}$ scanner.

Results:

- Significant reduction in signal intensity ratio of the liver was show in all patients.

- Highly significant correlation between MRI parameter (R2* and T2*) and LIC $(p<0.001)$.

- Moderate significant correlation between MRI parameters (R2*, T2*) and SF level when serum Ferrittin below 4000 $\mathrm{ng} / \mathrm{dl}$ and non-significant when SF above 4000ng/dl $(p>0.05)$.

- Splenectomizied patients had significant lower SIR of liver (decrease $\mathrm{R} 2 *$ and increase T2*) compared to non splenectomized patients $(p<0.007)$.

Conclusion: In conclusion based on results of our study MRI is the best noninvasive method for assessment and evaluation of hepatic iron overload and determine its severity in multi-transfused $\beta$-thalassemic patients.

Key Words: Thalassemic children - Hepatic iron overloadMRI.

\section{Introduction}

$\beta$-THALASSAEMIA major is a hereditary hemolytic anemia characterized by ineffective erythropoiesis and haemolysis. Thalassemia is a major

Correspondence to: Dr. Ali E.A. Agaln, The Department of Diagnostic Radiology, Faculty of Medicine, Tanta University health problem in Egypt since it is estimated that out of 1.5 million live births, 1000 children with thalassemia are born annually [1]

The underlying mechanism is defective production of haemoglobin $\beta$-chains, resulting in excess of $\alpha$-chains. This excessive intracellular deposition of $\alpha$-chain material is responsible for accelerated apoptosis of the erythroid precursors and for peripheral haemolysis of the erythrocytes [2]

By the age of 3 months, severe anaemia develops leading to increased intestinal iron absorption. To maintain haemoglobin at a level of $10-12 \mathrm{~g} / \mathrm{dl}$, patients suffering from $\beta$-thalassaemia major need to be given repeated blood transfusions [3]. A major drawback of this treatment is transfusion siderosis, which, in association with the increased intestinal iron absorption, apoptosis of the erythroid precursors and peripheral haemolysis, leads to iron overload, which leads to cell death and organ dysfunction [4]

Iron accumulates initially in the reticuloendothelial system (bone marrow, spleen, and liver) and then in the hepatocytes, the heart (myocytes), and the endocrine glands. The turnover of iron in the hepatocytes, myocytes, and endocrine glands is very low. Chelation therapy has been used to eliminate it [5]

The effective management of patients, and especially of children, with thalassaemia requires optimal monitoring of the toxic effects of both iron overload and excessive chelation therapy [6]

Serum ferritin has been widely used as a surrogate marker and a target ferritin level of 1,000 is generally recommended.

However, serum ferritin represents only $1 \%$ of the total iron pool, and as an acute phase protein it is not specific because the levels can be raised 
in inflammation (e.g. hepatitis) and liver damage [7]. Chronic liver inflammation is not rare in patients with thalassaemia, since over $40 \%$ of them have positive anti-Hepatitis C Virus (HCV) antibodies and more than $50 \%$ have chronic (persistent or active) hepatitis [8].

Liver Iron Concentration (LIC) measured on needle biopsy is currently considered the gold standard for the evaluation of siderosis. However, needle biopsy is an invasive technique, it is not easily repeatable and the accuracy of the resulting LIC measurement is greatly affected by hepatic inflammation-fibrosis and uneven iron distribution [9].

The use of non-invasive techniques for monitoring iron overload in each of the affected organs would be preferable, and to this end MRI has been used increasingly over the last two decades.

Magnetic Resonance Imaging (MRI) represents the most available noninvasive technique to assess hepatic iron content and shows a good correlation with biopsy results [10]

MRI is the best noninvasive method for measuring the level of iron in the liver for the purposes of confirming the diagnosis, determining the severity and monitoring therapy with high sensitivity, specificity, positive and negative predictive values and avoidance of repeated liver biopsy in followup of therapy [11]

Other non-invasive methodologies are too complex, too costly and not readily available (i.e. magnetic susceptometry), or lack imaging capability (i.e. magnetic resonance spectroscopy) [12]

\section{Patients and Methods}

This study was carried out upon 40 consecutive multi-transfused $\beta$-thalassaemic children (21 males and 19 females). These thalassemic children were selected from those attending for a medical checkup at the Hematology Unit, Pediatric Department, Tanta University Hospital and referred to MRI Unit of Radiodiagnosis Department; Tanta University Hospital during the period from December 2016 to June 2017. All patients were diagnosed as $\beta$-thalassemic major based on clinical examination and hematological evaluation,age ranged between 6 - 18 years with mean age $(10.500 \pm 2.572)$ and on regular blood transfusion $(5-10 \mathrm{ml}$ packed $\mathrm{RBCs} / \mathrm{kg}$ body weight) at 2-4 weeks interval to keep their haemoglobin level of 9-11g/dl befor each transfusion. Patients were receiving chelation theraby with subcutaneous deferoxamine mesylate 20-40 $\mathrm{mg} / \mathrm{kg}$ per day or oral desferasirox $30-40 \mathrm{mg} / \mathrm{kg}$ per day with variable complication.

The study was approved by the Ethical Committee of Faculty of Medicine, Tanta University. The patients were enrolled after obtaining an informed consent from their parents.

\section{Inclusion criteria:}

All patients mulitransfused previously diagnosed $\beta$-thalassemic children.

\section{Exclusion criteria:}

1- Liver decompansation.

2- Children ${ }^{<3}$ years old and older 18 years old.

3- Patients in whom MRI was contraindicated to perform:

A- Patients with intraocular metallic foreign body.

B- Patients with cardiac pace makers.

C- Patients with MR non-compatible intracranial aneurysmal clip.

4- Patients who refused MRI examination.

5- Acute systemic infection.

\section{Methods:}

All patients with thalassemia undergo: Complete history taking with special emphasis on: Age, sex, order of birth, consanguineous marriage, disease duration, family history of chronic hemolytic anemia and transfusion history (age of first blood transfusion, frequency and dose of transfusion per month), chelation history (age at start of chelation therapy, type and dose of chelating agents, compliance of patient to the treatment, complications) and history of splenectomy (its indication, age at the time of operation). And full examination: Anthropometric measures (weight, height \& head circumference), chest, heart, abdominal (liver, spleen and ascites) and neurological assessment were performed. The following laboratory investigations were done: Complete Blood Count (CBC), serum Ferritin Level (SF), liver function tests including: Total and direct serum bilirubin, liver enzymes (ALT, AST), total serum proteins, serum albumin, as well as Prothrombin Time (PT) and activity. Radiological evaluation of liver iron concentration measurement by MRI for the assessment of liver iron content using T2 gradient echo pulse sequence in the axial plane. Examination was done for all patients in MR Unit, Radiology and Imaging Department, Tanta University Hospital, using 1.5 tesla system (Toshiba, GE medical system). Preparation Before entering the examination room, the 
patients and their parents were instructed to remove all ferromagnetic objects like metallic objects. Patients were instructed about the importance of being calm with no motion throughout the time of examination.

\section{Technique:}

Multiple axial gradient images with the following parameters TE $(1 / 2.3 / 3.5 / 4.8 / 6.1 / 7.3 / 8.6 / 9.9)$ milliseconds.

- $\mathrm{TR}=16.3 \mathrm{msec} /$ echo time.

- Flip angle $=20$.

- Field of View $(F O V)=40$ X $38 \mathrm{~mm}$.

- Matrix (frequency X phase) $=128$ X 192 pixels.

- Slice thickness $=10 \mathrm{~mm}$ with no gap interval.

- Items needed for analysis of MRI images (post image processing).

- Spread sheet program that supports an MS-Excel file.

Software to draw Regions of Interest (ROIs) in the original MRI images.

- There is different software programs used widely for estimation of $\mathrm{T} 2 *$ and $\mathrm{R} 2 *$ [13]. We used Software named Short Axis Image cardiac R2* BH.

- Images were acquired in the scanner and imported into software for ROI drawing.
- Major vessels of liver were avoided and no need to cover the whole liver but it was sufficient to cover a large part of the right lobe.

- Each image showed a pair of numbers: The TE (echo time) and the mean Signal Intensity (SI) of the drawn ROI) as shown in Fig. (1).

- The TEs and ROI values were inserted in the two columns of the spread sheet.

- As we recorded the numbers, the graph and some values changed automatically.

- T2*, R2* and LIC were caluclated automatically [14].

- $\mathrm{T} 2 *$ represents the echo time necessary for a tissue to become twice as dark. Alternatively, image darkening can be expressed by R2* where it represents the rate of darkening. $\mathrm{R} 2 *$ is directly proportional to iron concentration.

- R2* values are simply $1000 / \mathrm{T} 2 *$ and vice versa.

Table (1): Ranges of different MRI parameters for measurement of liver iron concentration [15]

\begin{tabular}{lllll}
\hline & Normal & \multicolumn{1}{c}{ Mild } & Moderate & Severe \\
\hline $\mathrm{T} 2 *(\mathrm{~ms})$ & $>11.4$ & $3.8-11.4$ & $1.8-3.8$ & $<1.8$ \\
$\mathrm{R} 2 *(\mathrm{~Hz})$ & $<88$ & $88-263$ & $263-555$ & $>555$ \\
LIC $(\mathrm{mg} / \mathrm{g})$ & $<2$ & $2-7$ & $7-15$ & $>15$ \\
\hline
\end{tabular}

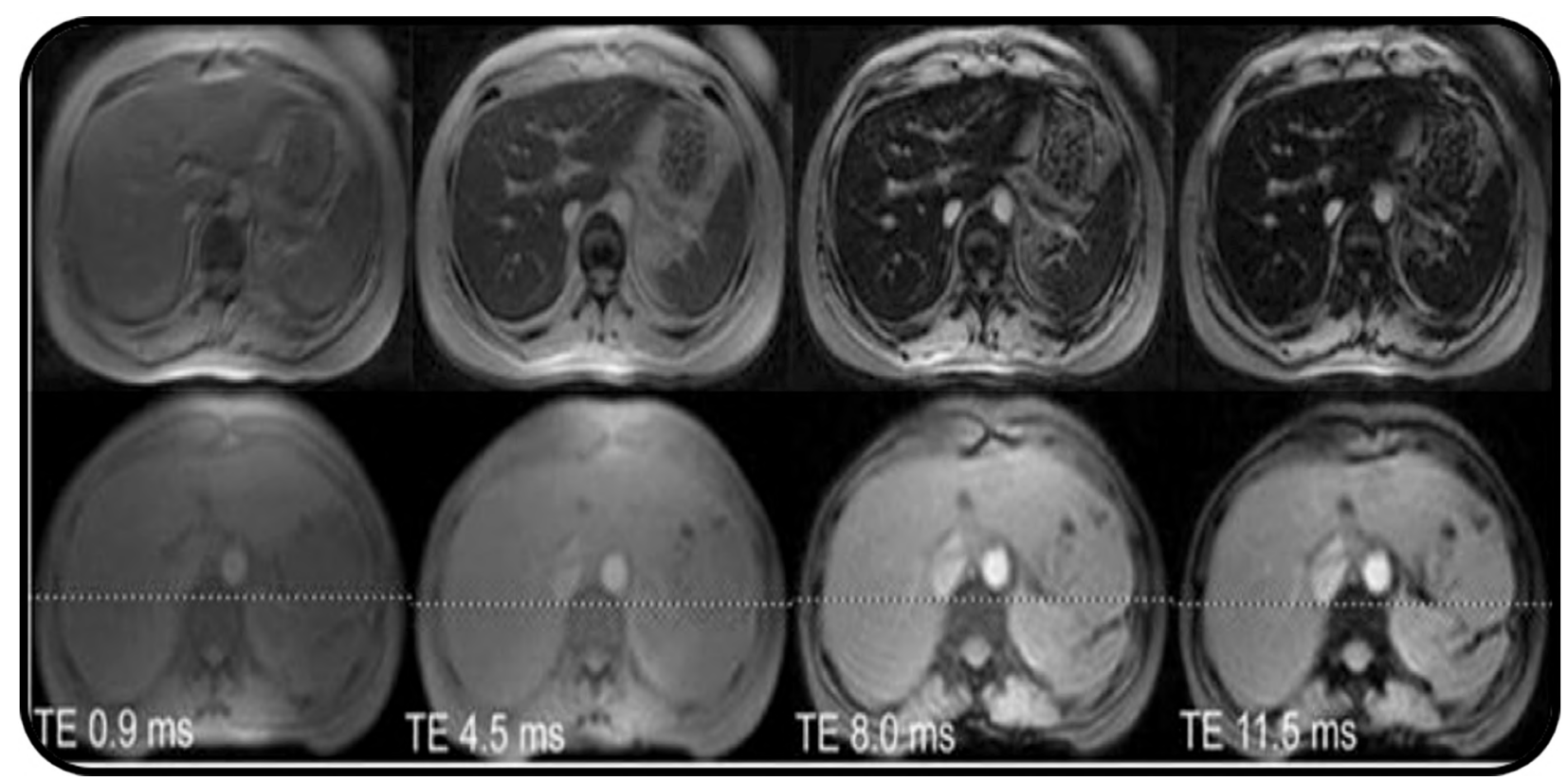

Fig. (1): Gradient echo images (T2*) of liver collected at four different echo times $[\mathbf{1 4 , 1 5}]$ 
Step 5-Opserve the results reported:

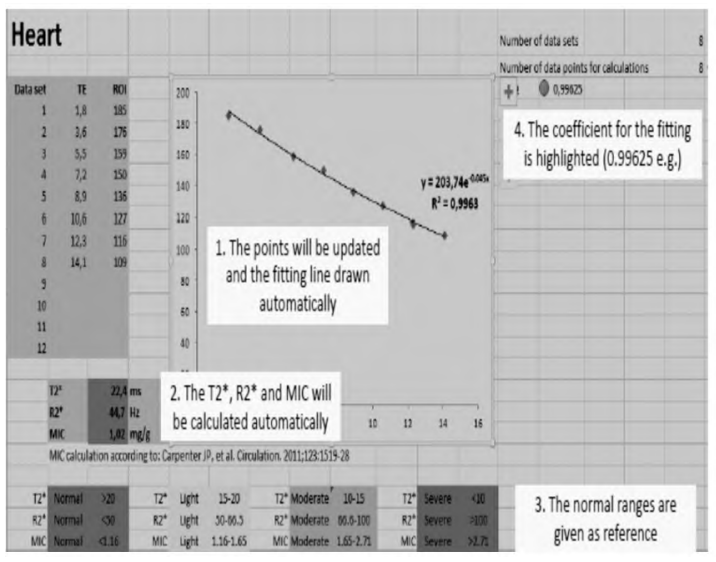

Step 6-Do the same for the liver (liver tab):

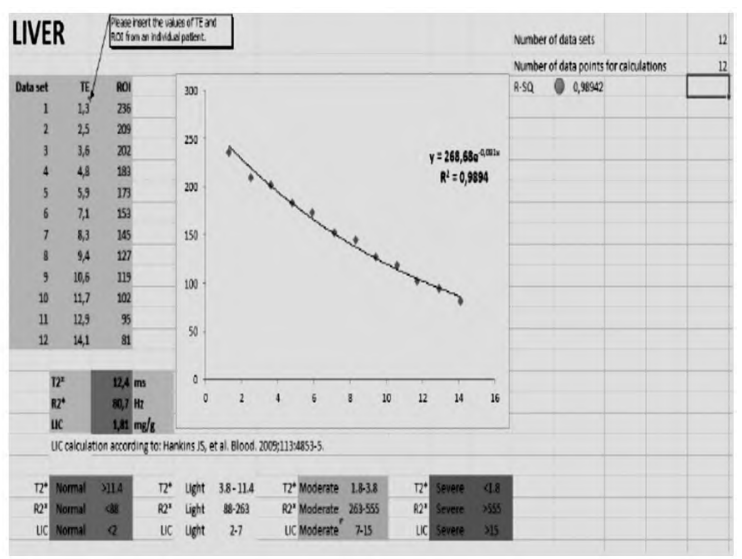

Fig. (2): Sample screenshot of the results section of the software with the automatic curve generation, T2*, R2*, and final liver iron displayed. Along with the results, the software also provides a reference table [15]

\section{Results}

Table (2): Show socio-demographic characteristics of all patients as regard to age, sex, family history to the disease and consanguinity.

\begin{tabular}{lll}
\hline \multicolumn{3}{c}{ Descriptive data } \\
\hline Age (Years): & $6-18$ \\
Range & $10.500 \pm 2.572$ \\
Mean \pm SD & \multicolumn{2}{l}{} \\
Duration (Years): & $3-14.5$ & \\
Range & $9.056 \pm 2.542$ & \\
Mean \pm SD & $\mathrm{N}$ & $\%$ \\
Sex: & 21 & 52.50 \\
Male & 19 & 47.50 \\
Female & & \\
Family history: & 18 & 45.00 \\
No & 22 & 55.00 \\
Yes & & \\
Consanguinity: & 12 & 30.00 \\
No & 28 & 70.0 \\
Yes & &
\end{tabular}

Table (3): Laboratory data of thalassemic of patients.

\begin{tabular}{ll}
\hline$B$ : & \\
$\quad$ Range & $8-11$ \\
Mean \pm SD & $9.365 \pm 0.898$ \\
Platelets: & \\
$\quad$ Range & $90-595$ \\
$\quad$ Mean \pm SD & $367.750 \pm 157.885$ \\
Serum ferritin: & \\
$\quad$ Range & $500-8000$ \\
$\quad$ Median (IQR) & $3475(2200)$ \\
ALT: & \\
$\quad$ Range & $38-66$ \\
$\quad$ Mean \pm SD & $51.000 \pm 9.435$ \\
AST: & \\
Range & $35-70$ \\
Mean \pm SD & $54.100 \pm 9.876$ \\
S. Albumin: & \\
$\quad$ Range & $1.8-3.9$ \\
Mean \pm SD & $3.090 \pm 0.548$ \\
WBCS: & \\
Range & $5.6-16$ \\
Mean \pm SD & $12.700 \pm 3.316$
\end{tabular}

Table (4): Show range of serum ferritin and MRI findings in fourty patients.

\begin{tabular}{llll}
\hline & \multicolumn{3}{c}{ Descriptive data } \\
\cline { 2 - 4 } & \multicolumn{1}{c}{ Range } & Median & $\begin{array}{c}\text { Interquartile } \\
\text { Range }\end{array}$ \\
\hline Serum ferritin $(\mathrm{ng} / \mathrm{ml})$ & $500-8000$ & 3475.000 & 2200.000 \\
$\mathrm{R} 2 *(\mathrm{HZ})$ & $99-938$ & 386.900 & 391.750 \\
$\mathrm{~T} 2 *(\mathrm{~ms})$ & $1-11.2$ & 2.900 & 4.675 \\
LIC $(\mathrm{mg} / \mathrm{g})$ & $2.56-22.51$ & 8.690 & 11.703 \\
\hline
\end{tabular}

Table (5): Show relation of MRI parameters and patients sex, family history and state of spleen.

\begin{tabular}{|c|c|c|c|c|c|}
\hline & \multicolumn{5}{|c|}{ Mann-Whitney test } \\
\hline & Range & Median & IQR & Z & $p$-value \\
\hline \multicolumn{6}{|l|}{$R 2 *(H Z)$} \\
\hline - Male & $99-734$ & 450.000 & 373.500 & 0.366 & 0.714 \\
\hline - Female & $100-938$ & 340.000 & 548.000 & & \\
\hline \multicolumn{6}{|l|}{$T 2 *(m s):$} \\
\hline - Male & $1-11.2$ & 2.700 & 4.700 & 0.583 & 0.560 \\
\hline - Female & $1.1-8.3$ & 4.000 & 4.100 & & \\
\hline \multicolumn{6}{|l|}{$R 2 *(H Z)$} \\
\hline • Not & $99-708$ & 340.000 & 303.500 & 2.116 & $0.034 *$ \\
\hline - Splenectomy & $150-938$ & 475.000 & 560.000 & & \\
\hline \multicolumn{6}{|l|}{$T 2 *(m s):$} \\
\hline • Not & $2.2-11.1$ & 4.000 & 5.500 & 2.686 & $0.007 *$ \\
\hline - Splenectomy & $1-6.8$ & 2.100 & 5.200 & & \\
\hline \multicolumn{6}{|l|}{$R 2 *(H Z)$} \\
\hline - -ve family history & $100-938$ & 420.000 & 521.000 & 1.525 & 0.127 \\
\hline - +ve family history & $99-720$ & 319.500 & 298.000 & & \\
\hline \multicolumn{6}{|l|}{$T 2 *(m s)$} \\
\hline - -ve family history & $1-8.3$ & 2.650 & 4.225 & 1.838 & 0.066 \\
\hline - +ve family history & $1.4-9.6$ & 3.750 & 4.925 & & \\
\hline
\end{tabular}

Table (5) show no significant difference between patients sex, family history and MRI parameters' but show significant increase R2* and significant decrease $\mathrm{T} 2 *$ in splenectomized patients. 


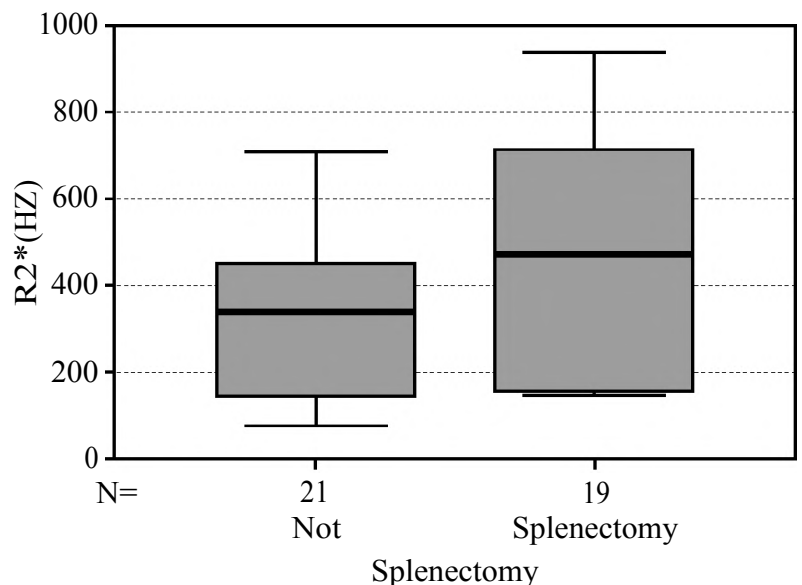

Fig. (1): Box-blot representing relation between R2* and state of spleen. Showed significant increase in R2* in splenectomized patients on comparison to patients with spleen .

Table (6): Show correlation of MRI parameters and serum ferritin after classification of patient according to Serum ferritin.

\begin{tabular}{ccc}
\hline \multicolumn{3}{c}{ Correlations } \\
\cline { 2 - 3 } Serum ferritin & \multicolumn{2}{c}{ Serum ferritin } \\
\cline { 2 - 3 } & \multicolumn{1}{c}{$r$} & $p$-value \\
\hline$<4000 n g / m l:$ & & \\
R2* $(\mathrm{HZ})$ & 0.446 & $0.004^{*}$ \\
T2* $(\mathrm{ms})$ & -0.349 & $0.033^{*}$ \\
$>4000 n g / m l:$ & & \\
R2* $(\mathrm{HZ})$ & 0.537 & 0.069 \\
$\mathrm{~T} 2^{*}(\mathrm{~ms})$ & -0.419 & 0.154 \\
\hline
\end{tabular}

Table (6) after classification of patient according to SF level, there are 15 patient with SF level $<4000 \mathrm{ng} / \mathrm{ml}$ and 25 patient with SF level $>4000$ $\mathrm{ng} / \mathrm{ml}$, there is moderate significant correlation between R2*, T2* and SF level in 25 patient less than $4000 \mathrm{ng} / \mathrm{ml}$ and the correlation become weak non significant when SF level above $4000 \mathrm{ng} / \mathrm{ml}$.

Table (7): Correlation between R2*, T2*, serum ferritin level in patient below $4000 \mathrm{ng} / \mathrm{ml}$, as well as clinical data and laboratory data of patients.

\begin{tabular}{lll}
\hline \multicolumn{2}{c}{ Correlations } \\
\hline & \multicolumn{2}{c}{$\mathrm{R} 2 *(\mathrm{HZ})$} \\
\cline { 2 - 3 } & \multicolumn{1}{c}{$r$} & $p$-value \\
\hline T2* (ms) & -0.738 & $<0.001^{*}$ \\
Serum ferritin & 0.446 & $0.004^{*}$ \\
Age (years) & -0.022 & 0.895 \\
Age of diagnosis (years) & -0.567 & $<0.001^{*}$ \\
Duration (years) & 0.224 & 0.165 \\
Transfusion rate (months) & -0.219 & 0.175 \\
HB & 0.207 & 0.200 \\
ALT & 0.201 & 0.213 \\
AST & 0.253 & 0.116 \\
S. Albumin & 0.133 & 0.414 \\
WBCS & 0.059 & 0.717 \\
Platelets & 0.200 & 0.216 \\
\hline
\end{tabular}

Table (7) show highly negative significant correlation between $\mathrm{R} 2 *$ and $\mathrm{T} 2 *$, moderate significant correlation between R2* and serum Ferritin level in patient less than $4000 \mathrm{ng} / \mathrm{l}$ and no significant correlation between R2* and clinical, lab data of all patients.

Table (8): Correlation between LIC and other MRI findings.

\begin{tabular}{ccc}
\multicolumn{2}{c}{ Correlations } \\
\cline { 2 - 3 } & \multicolumn{2}{c}{ LIC $(\mathrm{mg} / \mathrm{g})$} \\
\hline & \multicolumn{1}{c}{$p$} & $p$-value \\
\hline $\mathrm{R} 2 *(\mathrm{HZ})$ & 0.960 & $<0.001^{*}$ \\
$\mathrm{~T} 2 *(\mathrm{~ms})$ & -0.692 & $<0.001^{*}$ \\
\hline
\end{tabular}

Table (8) showed that there was significant negative correlation between LIC and T2* and significant positive correlation between LIC and $\mathrm{R} 2 *$.

\section{Discussion}

Beta-Thalassaemia major is a hereditary hemolytic anemia characterized by ineffective erythropoiesis and haemolysis. Thalassemia is a major health problem in Egypt since it is estimated that out of 1.5 million live births, 1000 children with thalassemia are born annually [1]

One of the major complication of 3 -Thalassaemia is iron overload because of repeated blood transfusion as a long term treatment which lead to cell death and organ dysfunction [4].

The effective management of patients, and especially of children, with thalassaemia requires optimal monitoring of the toxic effects of iron overload.

Serum ferritin has been widely used as a surrogate marker and a target ferritin level of 1,000 is generally recommended. However, serum ferritin represents only $1 \%$ of the total iron pool, and as an acute phase protein it is not specific because the levels can be raised in inflammation (e.g. hepatitis) and liver damage $[\mathbf{5 , 1 6}]$.

Chronic liver inflammation is not rare in patients with thalassaemia, since over $40 \%$ of them have positive anti-Hepatitis C Virus (HCV) antibodies and more than $50 \%$ have chronic (persistent or active) hepatitis [16]

Liver Iron Concentration (LIC) measured on needle biopsy is currently considered the gold standard for the evaluation of siderosis. However, needle biopsy is an invasive technique, it is not easily repeatable and the accuracy of the resulting 
LIC measurement is greatly affected by hepatic inflammation-fibrosis and uneven iron distribution [17].

Magnetic Resonance (MR) imaging is the most sensitive and specific imaging modality in the diagnosis of parenchymal iron overload in thalassemic patients on regular blood transfusion. The susceptibility effect caused by the accumulation of iron leads to signal loss in the affected tissues, particularly with the $\mathrm{T} 2 *$ weighted sequences, which makes the diagnosis of iron overload possible in a noninvasive way, thereby avoiding repeated biopsies [17].

On clinical examination of patients in this study, there were no significant differences among patients as regarding pallor, jaundice, hepatomegaly, splenomegaly and splenectomy as they were suffering from the same hemolytic disease. However, the percentage of patients who had splenectomy was insignificantly higher.

In our study, there were no significant correlations between LIC and age or sex. This result is in agreement with many previous studies [18-20] Who reported that there was no clear correlation between any $\beta$-thalassemic patients' characteristics (age, race, sex and rate of blood transfusion) and baseline LIC.

In our study there was significant increase in $\mathrm{R} 2 *$, LIC and decrease $\mathrm{T} 2 *$ in patients who had splenectomy however other studies like Olympia Papakonstantinou, et al., [21] and, Angelucci et al., [22]reported that splenectomy and its timing had little significant effect on LIC and total body iron. [23] and this is may be due to little number of cases in our study.

Our study showed that there was highly significant increase in LIC with associated significant changes in other MRI parameters (significantly decreased $\mathrm{T} 2 *$ and significantly increased $\mathrm{R} 2 *$ ) in patients. This result is in agreement with that described by Alústiza et al., [23] who reported that the larger the liver iron overload, the greater the decrease of Signal Intensity (SI) on MR images which is represented with $\mathrm{T}^{*}$ as liver parenchyma darkens progressively with increased echo time.

These results could be explained by the paramagnetic properties of iron that can affect susceptibility of tissue and produce changes in the magnetic field so that high iron overload lead to decrease in relaxation times (T2*, T2) and increase in relaxation rates $(\mathrm{R} 2, \mathrm{R} 2 *)$ [24]
Another explanation of this finding could be attributed to the mechanism of MRI which does not image the iron directly but instead images water protons as they diffuse near iron deposits in the tissue of interest such as heart and liver. The iron acts as little magnets, destroying the homogeneity of the magnetic field in iron laden tissues. The moving water protons each experience significantly different magnetic profiles and become desynchronized from one another. This causes the image to darken at a rate proportional to the iron concentration [25].

Another possible mechanism includes presence of tissue iron that introduces microscopic B0 field in homogeneities that result in rapid signal dephasing and increased rate of $\mathrm{R} 2 *$ relaxation in gradientecho images [26]. Also relaxation occurs through proton chemical exchange between bulk water and exchangeable protons bound to iron-containing proteins. Iron electrons enhance the relaxation of the protein-bound water protons. Through chemical exchange, enhanced relaxation of bound water protons is then transferred to the bulk water protons, leading to an R2 increase of bulk water. Regardless of the specific mechanism, it has been shown that R2 increases monotonically with LIC [27]

Our study showed highly negative significant correlation between $\mathrm{R} 2 *$ and $\mathrm{T} 2 *$ this is in agreement with Kidson-Gerber et al., [28] reported that a linear relationship between $\mathrm{T} 2 *$ and $\mathrm{R} 2 *$ with a correlation coefficient $(r)$ of $0.946, p<0.001$.

Our study showed that there was moderate signifcant correlation between R2*, T2* and Serum ferritin level when SF level below 4000ng/ml, and non-significant when SF level above 4000ng/ml.

Other study like Alexopoulou et al., [29] reported that R2* had significant positive correlation with Serum ferritin this is may be due small number of cases which carried only on 26 patients.

Other study Angulo et al., [30] confirmed that there was no correlation between SF and R2* and T2* assessed by hepatic MRI in thalassemic patients and this is may be due to more than half patients in this study had high SF level above $4000 \mathrm{ng} / \mathrm{ml}$.

Our study showed that the correlation between MRI parameters (R2* and T2*) and serum ferritin become non significant when serum ferritin above $4000 \mathrm{ng} / \mathrm{ml}$. This is in agreement with study by Azarkeivan et al., [31] reported that correlation between SF and liver T2* greatly weakened in patients with SF readings higher than $4000 \mathrm{~g} / \mathrm{ml}$. 
These results could be explained by many factors. Serum ferritin can be affected by the presence of hepatitis $\mathrm{C}$ which increases SF which determine allocation of iron between macrophages and parenchymal sites. Another explanation of this finding is that SF which is an acute phase reactant generated in response to inflammation, contains much less iron than normal ferritin and this is very apparent in patients with $\beta$-thalassemia and hepatitis $C$ virus Also, previous studies indicated that SF in contrast to tissue ferritin has low iron content even in iron loaded patients [32].

Interpretation of Serum Ferritin values may be complicated by a variety of conditions that alter concentrations independently of changes in the body iron burden including Vitamin C deficiency, fever, acute and chronic hepatic damage, hemolysis and ineffective erythropoiesis; all of which are common in patients with $\beta$-thalassemia major [35]

Also, Gandon et al., [33] reported that SF levels can be confounded by factors such as infection and inflammation resulting in inaccurate reflections of tissue iron concentrations. Additionally, it was reported that simple relationship between SF and liver iron stores can't be assumed when SF concentration exceeds $4000 \mathrm{ng} / \mathrm{ml}$, suggesting that secretion of glycosylated ferritin from reticuloendothelial cells reaches maximum with increasing iron accumulation reflecting maximum rate of synthesis.

\section{Summary and Conclusion:}

Our Study was carried out upon 40 multitransfused $\beta$-thalassaemic children. These thalassemic children were selected from those attending for a medical check-up at the Hematology Unit, Pediatric Department. And the study carried on the Department of Diagnostic Radiology Tanta University.

These fourty multi-transfused $\beta$-thalassemic children were subjected to clinical evaluation, appropriate laboratory assessment and assessment of LIC by MRI.

Our results show that the larger the liver overload, the greater the decrease of Signal Intensity (SI) on MR images which is represented with T2* as liver parenchyma darkens progressively with increased echo time.

Our study showed that there were significant negative correlation between LIC and T2* and significant positive correlation between LIC and $\mathrm{R} 2 *$.
Our study also reported moderate significant correlation between serum ferritin and R $2 *$ when SF level below $4000 \mathrm{ng} / \mathrm{ml}$, and the correllation become weak when serum ferritin above 4000

In conclusion based on results of our study MRI is the best non invasive method for assessment and evaluation of hepatic iron overload and determine its severity in multi-transfused $\beta$-thalassemic patients.

\section{Recommendations:}

At the end of this study we recommend that T2*GRE sequence in the protocol of MRI regular follow-up of $\beta$-thalassemic patients and for those under intensive chelation regimen as noninvasive tool that have no complication unlike needle biopsy and more accurate than serum ferritin nedded to assess the hepatic iron overload.

\section{References}

1- YOUSSEF S.M., EL-ALFY M.S., OSMAN A.L., KHAT TAB D.A., EL-FEKY M.A. and HUSSEIN M.E.: Rapid detection of multiple $\beta$-globin gene mutations by a realtime polymerase chain reaction in $\beta$-thalassemia carriers. Egypt J. Haematol., 37 (3): 147-55, 2012.

2- RUND D. and RACHMILEWITZ E.: Beta-thalassemia. N. Engl. J. Med., 353: 1135-46, 2005.

3- POOTRAKUL P., SIRANKAPRACHA P., HEMSORACH S., et al.: A correlation of erythrokinetics, ineffective erythropoiesis, and erythroid precursor apoptosis in Thai patients with thalassemia. Blood, 96: 2606-12, 2000.

4- FORGET B.G.: The pathophysiology and molecular genetics of beta thalassemia. Mt. Sinai J. Med., 60: 95-103, 1993.

5- HENTZE M.W., MUCKENTHALER M.U. and ANDREWS N.C.: Balancing acts: Molecular control of mammalian iron metabolism. Cell, 117: 285-97, 2004.

6- PORTER J.B. and DAVIS B.A.: Monitoring chelation therapy toachieve optimal outcome in the treatment of thalassaemia. Best Pract. Res. Clin. Haematol., 15: 32968, 2002.

7- MAZZA P., GIUA R., De MARCO S., et al.: Iron overload inthalassemia: Comparative analysis of magnetic resonance imaging, serum ferritin and iron content of the liver. Haematologica, 80: 398-404, 1995.

8- TONG M.J., EL-FARRA N.S., REIKES A.R., et al.: Clinical outcomes after transfusion-associated hepatitis C. N. Engl. J. Med., 332: 1463-6, 1995.

9- ANGELUCCI E., BARONCIANI D., LUCARELLI G., et al.: Needle liver biopsy in thalassaemia: Analyses of diagnostic accuracy and safety in 1184 consecutive biopsies. British Journal of Haematology, 89: 757-61, 1995.

10- WOOD C., ENRIQUEZ C., GHUGRE N., et al.: MRI R2 and R2-mapping accurately estimates hepatic iron concentration in transfusion-dependent thalassemia and sickle cell disease patients. Blood, 106: 1460-5, 2005. 
11- MARIA I. and LOUKAS A.: MRI evaluation of tissue iron burden in patients with $\beta$-thalassaemia major. Pediatr. Radiol., 37: 1191-200, 2007.

12- BRITTENHAM G.M. and BADMAN D.G.: Noninvasive measurement of iron: Report of an NIDDK workshop. Blood, 101: 15-9, 2003.

13- LORENZO BACIGALUPO, FRANCESCO PAPARO, et al.: Comparison between different software programs and post-processing techniques for the MRI quantification of liver iron concentration in thalassemia patients. La radiologia medica, 121PP752: 61, 2016.

14- FERNANDES J.L., SAMPAIO E.F., VERISSIMO M.P., et al.: Heart and liver T2* assessment for iron overload using different software programs. European Radiology, 21: 2503-10, 2012.

15- HANKINS J.S., McCARVILLE M.B., LOEFFLER R.B., et al.: R2* magnetic resonance imaging of the liver in patients with iron overload. Blood, 113: 4853-5, 2012.

16- TONG M.J., EL-FARRA N.S., REIKES A.R., et al.: Clinical outcomes after transfusion-associated hepatitis C. N. Engl. J. Med., 332: 1463-6, 1995.

17- MUSALLAM K.M., CAPPELLINI M.D., WOOD J.C., et al.: Elevated liver iron concentration is a marker of increased morbidity in patients with 3 -thalassemia intermedia. Hematologica, 96: 1605-12, 2011.

18- CAPPELLINI M.D., COHEN A., PIGA A., et al.: A phase 3 study of deferasirox (ICL670), a once-daily oral iron chelator, in patients with beta-thalassemia. Blood, 107: 3455-62, 2006.

19- MUSALLAM K.M., CAPPELLINI M.D., WOOD J.C., et al.: Elevated liver iron concentration is a marker of increased morbidity in patients with $\beta$-thalassemia intermedia. Hematologica, 96: 1605-12, 2011.

20- CAPPELLINI M.D., COHEN A., PIGA A., et al.: A phase 3 study of deferasirox (ICL670), a once-daily oral iron chelator, in patients with beta-thalassemia. Blood, 107: 3455-62, 2006.

21- MUSALLAM K.M., CAPPELLINI M.D., WOOD J.C., et al.: Elevated liver iron concentration is a marker of increased morbidity in patients with $\beta$-thalassemia intermedia. Hematologica, 96: 1605-12, 2011.

22- S. VERHALC, M. MOREL, et al.: Liver iron overload assessment by MRI R2* relaxometry in highly transfused pediatric patients: An agreement and reproducibility study; Diagnostic and Interventional Imaging; Volume 96, Issue 3, Pages 259-64, 2015.
23- ALÚSTIZA J.M., ARTETXE J., CASTIELLA A., et al.: MR quantification of hepatic iron concentration. Radiology, 230: 479-84, 2004.

24- DOUGLAS R. ROSING, PRADEEP GUJJA, et al.: Iron Overload Cardiomyopathy, Better Understanding of An Increasing Disorder. J. Am. Coll. Cardiol., 56 (13): 1001$12,2010$.

25- WOOD J.C. and GHUGRE N.R.: MRI assessment of excess iron in thalassemia. Sickle cell disease and other iron overload diseases. Hemoglobin, 32: 85-96, 2008.

26- GHUGRE N.R. and WOOD J.C.: Relaxivity-iron calibration in hepatic iron overload: Probing underlying biophysical mechanisms using a Monte Carlo model. Magnetic Resonance Med., 65: 837-47, 2011.

27- ST PIERRE T.G., CLARK P.R., CHUA-ANUSORN W., et al.: Non invasive measurement and imaging of liver iron concentrations using proton magnetic resonance. Blood, 105: 855-61, 2005.

28- CLARKE L., KIDSON-GERBER G., et al.: T2* MRI Correlates with R2 Liver Iron Concentration in Transfusion Dependent Thalassaemia. J. Hematol. Blood Disord., 2 (1): 102. doi: 10.15744/2455-7641.2.102, 2016.

29- ALEXOPOULOU E., STRIPELI F. and BARAS P.: R2 relaxometry with MRI for the quantification of tissue iron overload in beta-thalassemic patients. J. Magn. Reson. Imaging, 23: 163-70, 2006.

30- ANGULO I.L., CARNEIRO D.T., BAFFA O., et al.: Determination of iron-overload in thalassemia by hepatic MRI and ferritin. Rev. Bras. Hematol. Hemoter., 30: 449$52,2012$.

31- AZARKEIVAN A., HASHEMIEH M., AKHLAGHPOOR S., et al.: Relation between serum ferritin and liver and heart MRI T2* in beta-thalassemia major patients. East Mediterr Health J., 19: 727-32, 2014.

32- NIELSEN P., GUNTHER U., DURKEN M., et al.: Serum ferritin iron in iron overload and liver damage: Correlation to body iron stores and diagnostic relevance. J. Lab. Clin. Med., 135: 413-8, 2010.

33- GANDON Y., OLIVIÉ D., GUYADER D., et al.: Noninvasive assessment of hepatic iron stores by MRI. Lancet, 363: 357-62, 2004

35- OLIVIERI N.F. and BRITTENHAM G.M.: Final results of the randomized trial of deferiprone (L1) and deferoxamine (DFO). Blood, 90: 264-9, 2006. 


\section{تقييم تركيز الحديد الكبلى بالرثين المغناطيسى فى الآطفال الذين يعانون من الثلاسييميا الكبرى المئين}

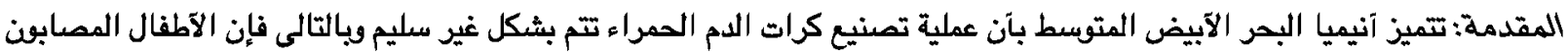

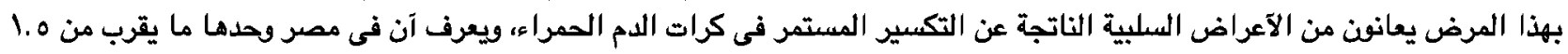

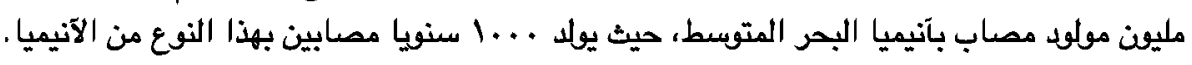

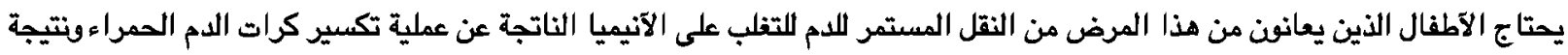

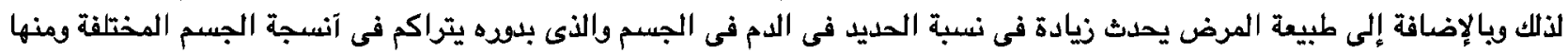

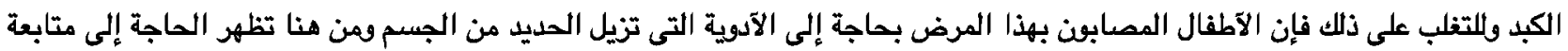
نسبة الحديد فى الجسم.

يبدآ الترسيب فى الكبد والطحال ونخاع العظام ثم القلب والغدد المفرزة مثل البنكرياس والغدم النخامية. الكبد هو آول الآعضاء التى يتم فيها ترسيب الحديد لذلك كمية ترسيب الحديد فيه تعطى فكرة عن كمية الترسيب المتوقعة فى الآعضاء

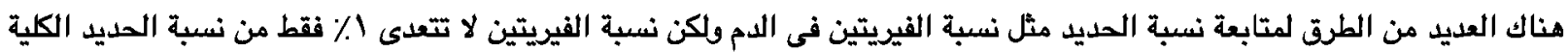

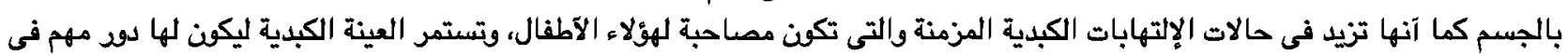

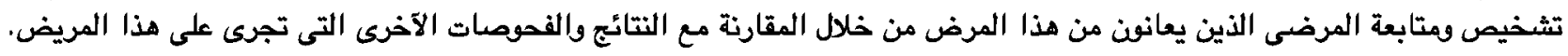

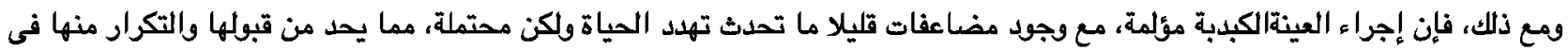

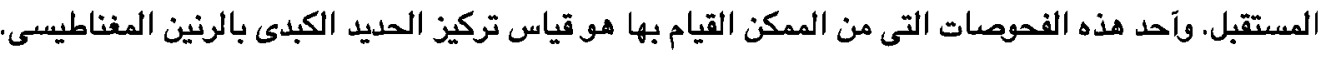

النتائج:

تم إجراء هذه الدراسة على آربعون طفل مصاب بالثلاسيميا الكبرى بينهم آ ذكر و19 آنثى ويتراوح متوسط آعمارهم بين T-1A عام وبعد إجراء الدراسة تبين لنا:

$$
\text { • • • • • }
$$

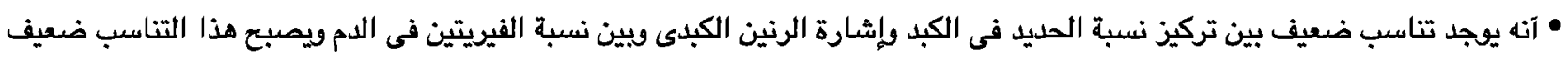

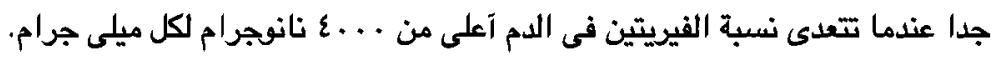
• مرضى الثُلاسيميا المستآصل طحالهم تنخفض إشارة الكبد فيهم فى الرنين المغناطيسى مقارنة بالغير مستآصل طحالهم. الفوائد والتوصيات: توفير إمكانية التشخيص الآمن والسريع لتركيز الحدزيد الكبدى ومتابعته بالرنين المغناطيسى فى الآطفال الذين يعانون من آنيميا البحر المتوسط (ثلاسيمية كبرى نمط بيتا). 